\title{
HIGH-ENERGY LASERS: PRINCIPLES, TYPES, INDICATIONS IN PERIODONTIAL PRACTICES
}

\author{
Dzhemileva T. ${ }^{1}$, Sl. Dimitrov², V. Dogandzhiyska ${ }^{3}$, Ts. Georgieva ${ }^{4}$, V. Kalchinov ${ }^{5}$, \\ V. Mantareva ${ }^{6}$, I. Angelov ${ }^{7}$, V. Kussovski ${ }^{8}$ \\ ${ }^{1}$ Centre for Periodontology and Diseases of the Oral Mucosa, Sofia; ${ }^{2}$ Department of Conservative \\ Dentistry and PD, Faculty of Dental Medicine, Medical University - Varna; ${ }^{3}$ Department of \\ Conservative Dentistry, Faculty of Dental Medicine, Medical University - Sofia; ${ }^{4}$ Department of \\ Conservative Dentistry, Faculty of Dental Medicine, Medical University - Sofia; ${ }^{5}$ Department of \\ Conservative Dentistry, Faculty of Dental Medicine, Medical University - Sofia; ${ }^{6}$ Institute of \\ Organic Chemistry with Centre of Photochemistry, Bulgarian Academy of Sciences, Sofia; \\ ${ }^{7}$ Institute of Organic Chemistry with Centre of Photochemistry, Bulgarian Academy of Sciences, \\ Sofia $;{ }^{8}$ Institute of Microbiology, Bulgarian Academy of Sciences, Sofia
}

\section{Reviewed by: assoc. prof. Ts. Uzunov}

\section{SUMMARY}

Investigations in the area of laser application in dental practices date back to 1964. Shortly after lasers came to being, they were introduced both in medicine and in dental medicine where they were successfully used for the diagnostics and treatment of a number of diseases. The current literature review presents the nature and properties of lasers and laser beams. Their biological and healing action is discussed. The most common lasers that are employed in dental practices are indicated. The accent is on high-energy lasers used in operative dentistry and periodontology, namely the Er:Cr:YSGG u Er:YAG lasers, and their emission characteristics. The focus in this literature review is on laser application in periodontal practices. The properties and indications of the most frequently applied lasers are indicated and their advantages are outlined. The latter are due to their specific biological and therapeutic effects both on healthy and on pathologically altered periodontal tissues. The paper also comprises clinical reports by renowned experts in periodontology about laser application in the treatment of different periodontial diseases.

Twenty-seven articles are cited.

Key words: high-energy /level/ lasers, Er:YAG laser, periodontitis, laser-assisted periodontial therapy, laser-assisted periodontial surgery

A whole long century was dedicated to the surgical treatment of the diseases of the oral cavity and the face. This resulted in the creation of an immense variety of dental instruments, as well as in the introduction and application of various types of anaesthetic and tranquilising medicines. In 1960, however, the renowned English journal 'Nature' issued T. H. Maiman's announcement entitled "Stimulated optical radiation in ruby" (3) that started the age of lasers. The first acting laser system, a solid state ruby laser, was developed by that same author, Teodor Maiman, a scientist from the Hugles Aircraft Corporation (19). Stern \& Sognnaes (25) и Goldman et al., 1964 (13) were the first to study the potential

Address for correspondence:

Sl. Dimitrov, Dept. of Conservative Dentistry and PD

Faculty of Dental Medicine, Medical University -Varna

Home address: 1619 Sofia, 20 Paskal Tododrov Str.

Tel. 00359-889/41-90-67

e-mail: slav_dimitrov45@abv.bg application of lasers in dental medicine. The initially developed laser systems had wavelengths that were suitable for manipulating soft tissues only. Later, systems were developed that could treat bones and hard dental tissues.

It took Goldman and associates (5) just five years to start using laser beams in the painless removal of tattoos where the outcome was a "gentle cicatrix" instead of a rough scar. It didn't take long to create lasers that could influence the enamel and the dentine, the epithelium and the cellular tissue (vessels: arteriolae, veins and capillaries; cellular tissue fibres, etc.), as well as the retina. Can anyone calculate precisely how many people have been saved from blindness due to the laser treatment of the retina? Recently, lasers have been used in implantology as well. Lasers are being extensively employed in various diseases of all areas of the human body.

The term LASER is actually an acronym of "Light Amplification by Stimulated Emission of Radiation" used by 
High-energy lasers: principles, types, indications in periodontial practices

Table 1: Lasers Applied in Periodontology

\begin{tabular}{|c|c|c|c|c|c|}
\hline Type of laser & $\begin{array}{c}\text { Wavelength } \\
/ \mathbf{n m} /\end{array}$ & Shape of wave & Contact & Conducting system & Application in Periodontology \\
\hline $\begin{array}{l}\text { Carbon dioxide } \\
\text { type of laser } / \mathrm{CO}_{2} /\end{array}$ & 10600 & $\begin{array}{l}\text { Controlled or } \\
\text { constant radiation }\end{array}$ & $\begin{array}{l}\text { The ray is focused } \\
\text { at a distance of } 1 \text { or } \\
2 \mathrm{~mm} \text { from the } \\
\text { target surface }\end{array}$ & $\begin{array}{c}\text { Hollow conductor of } \\
\text { the laser beam / an } \\
\text { arm with joints / }\end{array}$ & $\begin{array}{l}\text { Soft tissue incision and ablation, } \\
\text { sub-gingival abrasion, biopsy, } \\
\text { decontamination of implants }\end{array}$ \\
\hline $\begin{array}{l}\text { Neodymium: } \\
\text { Yttrium-Aluminiu } \\
\text { m-garnet } \\
\text { /Nd:YAG/ }\end{array}$ & 1064 & Pulsations & $\begin{array}{l}\text { Contact with the } \\
\text { surface is necessary }\end{array}$ & $\begin{array}{c}\text { Flexible fibre optic } \\
\text { system }\end{array}$ & $\begin{array}{l}\text { Soft tissue incision and ablation, } \\
\text { sub-gingival abrasion, bacteria } \\
\text { elimination }\end{array}$ \\
\hline $\begin{array}{l}\text { Erbium: } \\
\text { Yttrium-Aluminiu } \\
\text { m-garnet /Er:YAG/ }\end{array}$ & 2940 & $\begin{array}{c}\text { Free } \\
\text { /independently/ } \\
\text { occurring } \\
\text { pulsations }\end{array}$ & $\begin{array}{l}\text { Contact with the } \\
\text { surface is necessary }\end{array}$ & $\begin{array}{c}\text { Flexible fibre optic } \\
\text { system or a hollow } \\
\text { conductor of the laser } \\
\text { beam }\end{array}$ & $\begin{array}{l}\text { Soft tissue incision and ablation, } \\
\text { sub-gingival abrasion, odontolith } \\
\text { removal, root surface planing, } \\
\text { osteoplasty, osteotomy, degranulation } \\
\text { and decontamination of implants }\end{array}$ \\
\hline $\begin{array}{l}\text { Erbium, } \\
\text { Chromium: } \\
\text { Yttrium-Selenium- } \\
\text { Gallium-garnet } \\
\text { /Er:Cr:YSGG/ }\end{array}$ & 2780 & $\begin{array}{c}\text { Free } \\
\text { /independently/ } \\
\text { occurring } \\
\text { pulsations }\end{array}$ & $\begin{array}{l}\text { Contact with the } \\
\text { surface is necessary }\end{array}$ & $\begin{array}{l}\text { Fibre optic handle } \\
\text { with air cooling }\end{array}$ & $\begin{array}{l}\text { Soft tissue incision and ablation, } \\
\text { sub-gingival abrasion, odontolith } \\
\text { removal from the root surface, } \\
\text { osteoplasty, osteotomy }\end{array}$ \\
\hline Argon laser /Ar/ & 488 and 514 & $\begin{array}{l}\text { Controlled or } \\
\text { constant radiation }\end{array}$ & $\begin{array}{l}\text { No contact with the } \\
\text { treated surface is } \\
\text { necessary }\end{array}$ & $\begin{array}{l}\text { Flexible fibre optic } \\
\text { system }\end{array}$ & Soft tissue incision and ablation \\
\hline $\begin{array}{l}\text { Indium-Gallium-Ar } \\
\text { senic-Phosphorus }\end{array}$ & 635 to 950 & $\begin{array}{l}\text { Controlled or } \\
\text { constant radiation }\end{array}$ & $\begin{array}{l}\text { Contact with the } \\
\text { surface is necessary }\end{array}$ & $\begin{array}{l}\text { Flexible fibre optic } \\
\text { system }\end{array}$ & $\begin{array}{l}\text { Soft tissue incision and ablation, } \\
\text { sub-gingival abrasion, bacteria } \\
\text { elimination }\end{array}$ \\
\hline $\begin{array}{l}\text { Erbium: } \\
\text { Yttrium-Aluminiu } \\
\text { m-garnet /Er:YAG/ }\end{array}$ & 2940 & $\begin{array}{c}\text { Free } \\
\text { /independently/ } \\
\text { occurring } \\
\text { pulsations }\end{array}$ & $\begin{array}{l}\text { Contact with the } \\
\text { surface is necessary }\end{array}$ & $\begin{array}{c}\text { Flexible fibre optic } \\
\text { system or a hollow } \\
\text { conductor of the laser } \\
\text { beam }\end{array}$ & $\begin{array}{l}\text { Soft tissue incision and ablation, } \\
\text { sub-gingival abrasion, odontolith } \\
\text { removal, root surface planing, } \\
\text { osteoplasty, osteotomy, degranulation } \\
\text { and decontamination of implants }\end{array}$ \\
\hline
\end{tabular}

Maiman (3) because a ruby crystal was employed that emitted coherent radiation when stimulated by energy, in accordance with the theory postulated by Albert Einstein. Laser light is monochromatic light from the visible and the invisible spectrum and it has three major characteristic features: it is 1) collimated ${ }^{1}, 2$ ) coherent, and 3) efficient. The wave photon produced by different laser appliances can be defined on the basis of its velocity (speed), amplitude, and wavelength.

We are going to attempt an explanation of what goes on inside the laser tool through the diagram of the basic laser components introduced by V. Bains, S. Gupta, R. Bains (Fig. 1).

Amplification occurs in the optical cavity in the centre of the laser tool that consists of two parallel mirrors, one at each end of the tool. The inside of this cavity comprises chemical elements, components or molecules in gas, crystalline or solid semi-conductor form, known as "active medium", that gives the generic name of the respective laser. The pump source (a flash lamp strobe device or electrical coil) envelops the optical cavity that provides energy to the active medium. Some other constituents of a laser are the cooling system, the focusing lenses, etc. "Spontaneous emission can be defined as a process whereby a light source (an atom, a molecule, a nanocrystal, or a nucleus in an excited state) undergoes transition to a basic (non-excited) state (i.e. one with the lowest energy level of the atomic particle) and emits a photon. Atoms in laser tools are main-

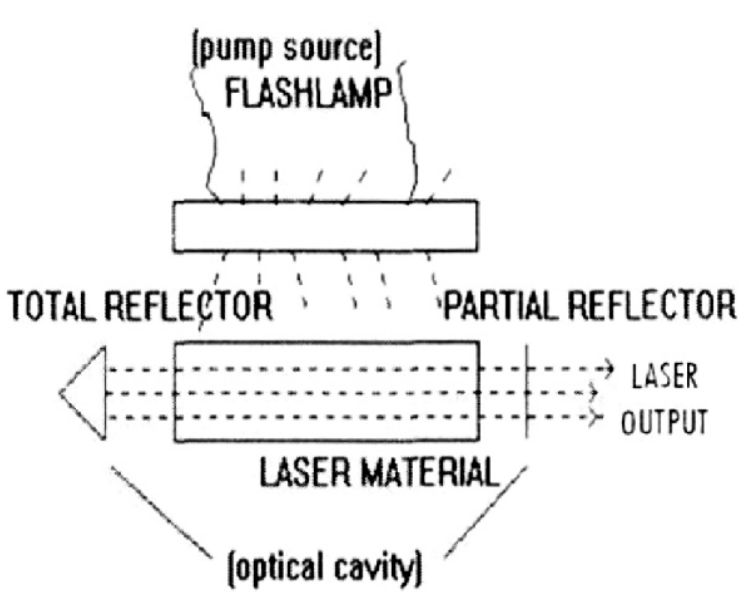

Fig.1. Diagram showing basic components of laser 
tained in an excited state through laser pumping that includes many photons. This pumping causes stimulated emission with certain atoms and, as a result, photons make other atoms undergo stimulated emission. A chain reaction like this generates intensive coherent light that is easy to focus" (Bains).

Lasers cause emissions which are, in their essence, light waves as a form of electromagnetic energy. With dental lasers, light wave emissions range from $500 \mathrm{~nm}$ to $10600 \mathrm{~nm}$. Those are within the visible and the invisible infrared part of the electromagnetic spectrum and emit thermal radiation.

Today, dental practice makes use of the following most common lasers: $\mathrm{CO}_{2}$, Nd: YAG, Ho: YAG, Er: YAG, Er,Cr:YSGG, Nd:YAP, GaAs (diode) and Ar (18).

The application of Er-lasers in dentistry is multilateral. They are used in the removal of soft tissue and in the disinfection of root canals in endodontics. They are also alternatives to high-revolution tips in oral and maxillofacial surgery when it comes to bone ablation. Besides, they are employed in the preparation of all classes of cavities (I-V) in temporal and permament. Further, they remove non-metallic obturations (composite material, glass-ionomer cement, compomer). They can not ablate metal (amalgam or gold) (16) and porcelain obturations, but after those are removed, a laser can be employed to remove the secondary and/or residual caries below (26).

\section{Er-lasers employed in dentistry are two major types} (7,9,15):

1. the Er: Cr: YSGG laser with a wavelength of $2780 \mathrm{~nm}$, with an active medium of solid crystal Yttrium-Scandium-Gallium-garnet with admixtures of Erbium and Chromium.

2. the Er: YAG laser with a wavelength of $2940 \mathrm{~nm}$, with an active medium of Yttrium-Aluminium-garnet with admixtures of Erbium.

With both types of laser, emissions are in the medium infra-red, invisible, non-ionised part of the spectrum. In order to obtain accuracy of irradiation, as well as to visualise the laser beam, a pilot ray by a He-Ne laser is necessary with an emission of $0,03 \mathrm{~W}$ that has no therapeutic effect but allows the operator to guess the direction of the beam (1).

The Er: YAG laser emission uses a hollow conductor of light waves or an optical fibre as a conducting medium, whereas the Er: Cr: YSGG-laser uses only a fibre optic system (8). At the end of each conducting system, a tip and a glass tip focus laser energy towards the irradiation spot with a diametre of approximately up to 0,5 micrometres.

The optimum therapeutic effect on tissues is obtained when using radiation with a wavelength that is best absorbed by the irradiated tissue. The closer the wavelength is to the absorption maximum of the tissue, the more pronounced the cutting properties of the laser beam are. It has been established that water absorbs 10 times more the radiation by an Er: YAG laser in comparison to that by $\mathrm{CO}_{2}$ laser, and 20000 times more as compared to the irradiation produced by a Nd:YAG laser (21). The emissions of all Er: YAG lasers are absorbed, to a very large extent, by water (the absorption maximum of laser energy in water is 3 micrometres and 10 micrometres), by the hydroxylapatite, and by the collagen which are the main constituent elements of the ТЗТ (11).

Here is a list of the power values that are most frequently used in laser irradiation for the treatment of oral cavity tissue: ENAMEL - 4-8 W (6 W on the average); DENTINE$2-5 \mathrm{~W}$ ( $4 \mathrm{~W}$ on the average); CARIES - 1-3 W ( $2 \mathrm{~W}$ on the average); BONE - 1,5-3 W; SOFT TISSUE - 1-3 W (14). The major principle in the application of Er: YAG-radiation is to use the lowest possible values within the course of the whole treatment (16).

Er-laser irradiation has a pronounced bactericidal effect $(2,14)$. Emissions are absorbed by the water in the bacterial cells and this leads to the evaporation of water, just as in the ablation of hard tissue. Some authors make use of the bactericidal effect of the Er-lasers to reduce the number of micro-organisms in the tiny dentine canals before placing the obturation with a cavity preparation through conventional borers.

In 2010, Bains, Gupta and Bains made a systemic arrangement of the properties and medical indications of the lasers that are mostly used in periodontal practice. Here is their table 1 :

The table reveals the opportunities and indications for applying lasers in the treatment of hard dental issue, endodontis and periodontis $(3,4,5,6,10,12,17,18,20,22,23,24,27)$.

Laser treatment results in minimum post-operative oedema, insignificant bleeding, slightly visible cicatrix due to the coagulation of proteins on the vulnerary surface which determines the insignificant pain experienced during the healing process, as well as the slight recession of the gingival $\mathrm{rib}$ and the gingival papilla.

Contemporary lasers account for the better detection and removal of sub-gingival odontolith, as well as for the processing of the alveolar process of the jaw-bone. They take effect in the removal of the sub-gingival anaerobic Gram negative microflora which is the major etiological factor and a pathogene in the development of periodontitis, respectively in the deepening of periodontal pockets. Not only has degranulation of periodontal pockets taken effect, but also Aggregatibacter actynomicetemcomitans has been reduced when applying an Er:YAG laser which is of extreme importance with aggressive varieties of periodontitis. The Er:YAG type of laser can also be used in cases when applying regenerative therapy to periodontal pockets through derivatives of the enamel matrix, as is Emogain by Straumann (4).

Among the advantages of applying lasers in clinical practice, it is worth mentioning the following:

- accuracy of procedures;

- deep penetration - bacteria are exterminated at a depth of 1.5 milimetres within the dentine tubulae;

- selective photo-thermal ablation of the erubescent inflamed tissue;

- bactericidia, particularly prominent with black-pigmented bacteria (those are especially significant with deep periodontal pockets);

- effect on odontolith which is easily removed following procedures with lasers; 
- neutralisation of tissue endotoxins;

- bio-stimulation of stem cells in the periodontal ligament that causes regeneration;

- haemostasis;

- less recession;

- much less sensitivity of the dentine;

- faster healing process;

- minimum post-operative discomfort due to the reduction of prostaglandins;

- $\quad$ reduced stress, both for the patient and the staff.

The limitations when applying lasers include:

- $\quad$ high price of laser tools;

- $\quad$ special training;

- $\quad$ safety precautions during manipulations;

- not all periodontal pockets respond uniformly; for example, the effect with smokers is much less prominent; generally speaking, within $90 \%$ of pockets the depth reduction of the pocket amounts to $50 \%$ (i.e. out of a $10-\mathrm{mm}$ pocket, $5 \mathrm{~mm}$ are reduced; with an 8-mm pocket $4 \mathrm{~mm}$ are reduced, etc.);

- just as in flap surgery, Class II and Class III furcations still pose problems.

The shorter healing process reduces or eliminates the need of job absences.

Laser treatment is preferable with patients who intake Aspirin on a daily basis. It is not necessary to stop administering the medication prior to the procedure. It is also worth mentioning the rapid extermination of the microflora in the periodontal pockets, particularly with patients who have systemic ailments.

St. Brown (who has a clinical practice in Philadelphia) offers a 7-step laser treatment in periodontics (Fig. 2):
4. to avoid the epithelium from penetrating into the pockets, blood coagulum should be carefully preserved (barrier membranes are not necessary),

5. the soft tissue and the bone start attaching to the clean root surface,

6. traumatic occlusion should not be not allowed,

7. a new cellular tissue attachment is observed, bone growth commences.

The author outlines the three visits to be made by patients:

First visit - diagnostics, including radiography and taking of material for microbiological analysis (if indicated).

Second visit - medical treatment is recommended. Third visit - laser treatment that is usually completed within a single visit.

The patient can resume performing their occupational duties on the very next day.

Interest in lasers in dental, respectively periodontal practices is on the rise. It is necessary to point out, however, that their high prices pose certain limitations to the application of these tools. To those we should also add the need of safety precautions (not merely goggles for patient and staff) during laser operation. The leading principle is primum non nocere, i.e. the Latin saying for "What matters is to do no harm!" This is not so hard to achieve provided the accurate approach to working with the respective laser tool is taken into consideration, as well as the specific ailment of the patient and their background pathology is regarded.

${ }^{1}$ Collimated light - Light whose rays are almost parallel, therefore they diffuse slower when they distribute (sometimes it is referred to as 'light that is focused in infinity').

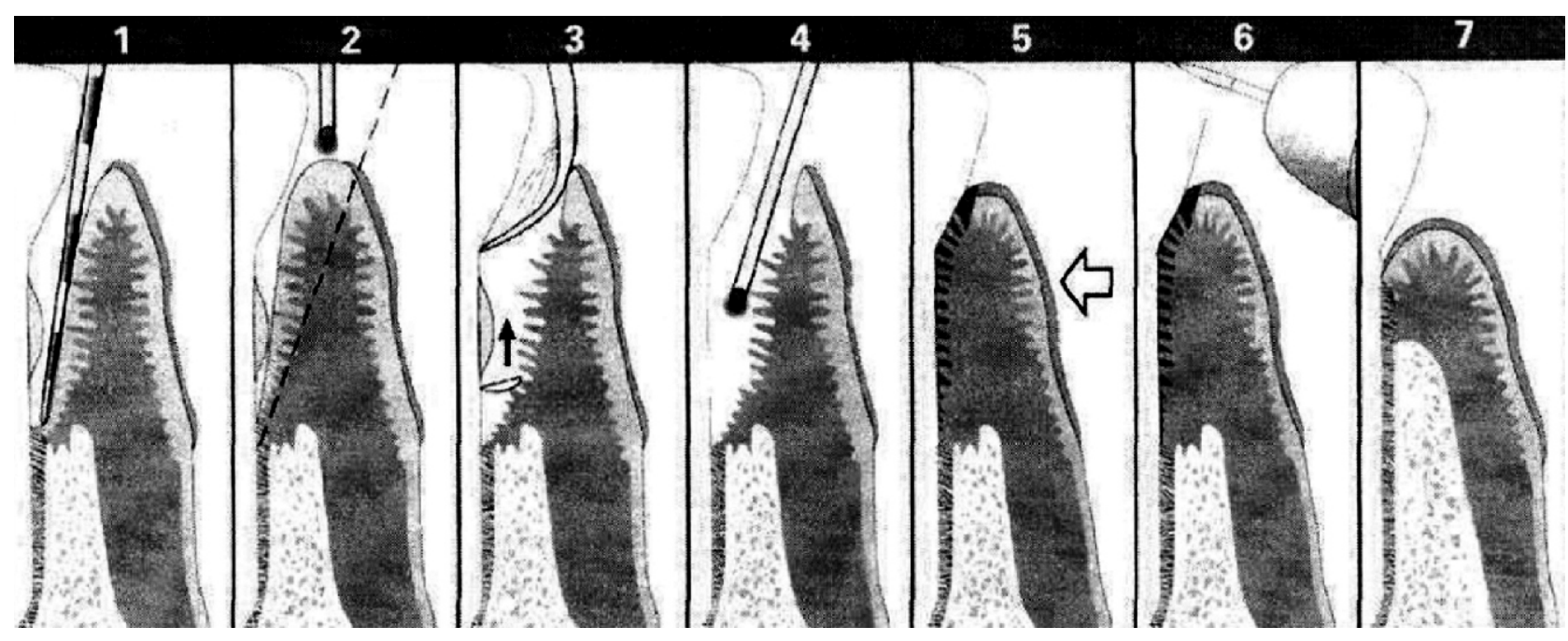

Fig. 2. Laser treatment procedure in seven steps

1. the pocket depth is measured by means of a periodontal drill,

2. microorganisms and unhealthy tissue are removed by means of a laser,

3. odontolith on the root surface is removed by means of an ultra-sound Piezo-scaler and manual tools,
The term is often associated with "collinear". Theoretically, collimated light should not diffuse; in practice, it diffuses to a minimum extent. Light collimation occurs through various processes, for example, with the aid of a collimator. 
Acknowledgements: We fully appreciate the support by the Scientific Research Fund at the Ministry of Education and Science for funding the scientific project, Contract № DO $177 / 16^{\text {th }}$ December 2008.

\section{BIBLIOGRAPHY}

1. Bill, G. The master is previsely in the wave's length (use of different types of laser in clinical practice). Dental almanac, 2004, October, 156-163.

2. Gutknecht, N. Laser therapy in endodontics. Dental almanac, 2004, October, 144-151.

3. Academy Report. Lasers in Periodontics. Research, Science and Therapy Committee of the American Academy of Periodontology. J. Periodontol. 2002,73,1231-1239.

4. Bains, V. K., S. Gupta, R. Bains. Lasers in Periodontics. An Overview. J. of Oral Health Comm.Dent, 2010, 4 (Spl.), 29-34.

5. Broun, I. St. Presenting a New Breakthrough in Periodontal Therapy: LANAP. Center for Laser Periodontics and Implants. PerioDontaLetter.

6. Cobb, Ch. M., S. B. Low, D. J. Coluzzi. Lasers and the Treatment of Chronic Periodontitis. Dent. Clin. N. Am., 54, 2010, 35-53.

7. Coluzzi, D. Fundamentals of dental lasers: science and instruments. Dent Clin N Am, 48, 2004, 751-770.

8. Convissar, R. The biologic rationale for the use of lasers in dentistry. Dent Clin N Am, 48, 2004, 771-794.

9. Dederich, D. et al. Lasers in dentistry. JADA, 135, 2004, February, 204-210.

10. Feitosa, D. da Silva, et al., Use of the diode Laser in the nonsurgical treatment of periodontal pockets. Odontologia Clin.-Cientif. Recife 2007, 6(2), 129-132.

11. Frentzen, M., H. Koort, I. Thiensiri. Excimer lasers in dentistry: future possibilities with advanced technology. Quintessence International, 23, 1992, 2, 117-133.

12. Gaspirc, B., U. Skaleric. Lasers in Periodontics. J. Oral Laser Applications, 3, 2003, 3, 135-140.
13. Goldman, L., J. Gray, J. Goldman et al. Effects of laser impacts on teeth. J Am Dent Assos, 70, 1965, 601-6.

14. Hibst, R., U. Keller. Experimental studies of the application of the Er:YAG laser on dental hard substances. I. Measurement of the ablation rate. Lasers Surg Med, 9, 1989, 338-44.

15. Kimura, Y., P. Wilder-Smith, K. Matsumoto.Lasers in endodontics: a review. International Endodontic Journal, 33, 2000, 173-185.

16. Kotlow, L. Lasers in pediatric dentistry. Dent Clin NAm, 48, 2004, 889-922.

17. Lee, D., Application of Laser in Periodontic: A New Approach in Periodontal treatment. Dental Bulletin. 12, 2007, 10, 23-25.

18. Mahajan, A., Lasers in Periodontics - A Review. Europ. J. of Dentistry and Medicine. 2010, ISSN, 1996-3378, p. 1-11.

19. Mainman, T. Stimulated optical radiation in ruby. Nature, 187, 1960, 493-4.

20. Martineau, M., Laser-assisted Periodontal Therapy. Dental Products Report. 2002, A Medical Economics Company.

21. Paghdiwala, A. Does the laser work on hard dental tissue? J Am Dent Assos, 122, 1991, 79-80.

22. Peng, T. K. Clinical applications of Er:YAG lasers in implant Patients. I $^{\text {st }}$ International Dental Implant Conference in Taiwan 2008.

23. Romanos, G. E. et al. Removal of Epithelium in Periodontal Pockets following Diode (980 nm) Laser Application in the Animal Model: An in vitro Study. Photomedicine and Laser Surgery. 22, 2004, 3, 177-183.

24. Schwarz, F et al. Periodontal treatment with an Er:YAG Laser or Scaling and Root Planing. A 2-Year Follow-Up Split-Mouth Study. Periodontol., 74, 2003, 5, 590-596.

25. Stern, R., R. Sonnaes. Laser beam on dental hard tissues. J Dent Res, 43, 1964, 873.

26. Strauss, R., S. Fallon. Lasers in contemporary oral and maxillofacial surgery. Dent Clin N Am, 48, 2004, 771-794.

27. Vanaja, K. N., S. Sangeetha, J. Dhayanand. Lasers in Periodontics - A scientific boon or bane? SRM University Journal of Dental Sciences, 1, 2010, Issue 1, June, 91-98. 